[RAdiocarbon, Vol. 9, 1967, P. 530-544]

\title{
UNIVERSITY OF WISCONSIN RADIOCARBON DATES III
}

\author{
MARGARET M. BENDER, REID A. BRYSON, and \\ DAVID A. BAERREIS
}

Department of Meteorology, University of Wisconsin, Madison

This report summarizes the radiocarbon dates obtained at the University of Wisconsin since November, 1965; the procedures followed and equipment used have been described previously (Wisconsin II).

The dates reported have been calculated on the assumption of a half-life of 5568 yr for $\mathrm{C}^{14}, 1950$ as the reference year. Samples have normally been run at $3 \mathrm{~atm}$ pressure for a minimum of 15,000 counts. The standard deviation quoted includes only the $l_{\sigma}$ of the counting statistics of background, sample, and standard counts.

Through the courtesy of Dr. R. H. Burris of the Biochemistry Department, it was possible to determine $\mathrm{C}^{13} / \mathrm{C}^{12}$ ratios of some samples of $\mathrm{CO}_{2}$ gas before its conversion to methane. The samples so analyzed are indicated in the text. The mass spectrograph used was Consolidated Engineering Corporation Model 21-201.

ACKNOWLEDGMENTS

This research is supported by the National Science Foundation, Atmospheric Sciences Division Grant GP-5572X, and National Science Foundation, Social Sciences Division Grants GS-1141 and GS-433. We are indebted to Robert J. Boettcher and Donald Green for the $\mathrm{C}^{13} / \mathrm{C}^{12}$ analyses.

SAMPLE DESCRIPTIONS

I. ARCHAEOLOGIC SAMPLES

A. Panhandle Aspect Series, Texas and Oklahoma

Dates are continuation of dating program designed to test hypothesis regarding relationship of occupation of Panhandle region by farming peoples and the climatic shift dated around A.D. 1250 (Wisconsin II, 1966). Provisional results (Baerreis and Bryson, 1966) confirm association of the occupation of Panhandle region and the Pacific climatic episode.

WIS-109. P-PHM Site A-547, Texas

$680 \pm 70$

Charcoal from vandal's pit in Panhandle aspect village near Canadian River $\left(36^{\circ} 00^{\prime} \mathrm{N}\right.$ Lat, $101^{\circ} 07^{\prime}$ W Long). Coll. 1962 by J. T. Hughes; subm. by D. A. Baerreis.

\section{P.PHM Site A-439, Texas}

Charcoal from P-PHM Site A-439, a Panhandle aspect or Washita River focus house, near $\mathrm{N}$ fork of Red River (35 $28^{\prime} \mathrm{N}$ Lat, $100^{\circ} 39^{\prime}$ 
W Long). Coll. 1960 by Jack T. Hughes, Panhandle Plains Hist. Soc., Canyon, Texas; subm. by D. A. Baerreis.

WIS-117. Site A-439

From house fill.

WIS-120. Site A-439

Sample from floor near fire-pit.

WIS-128. Site A-439

From floor near fire-pit.
$440 \pm 75$

A.D. 1510

A.D. 1350

$600 \pm 85$

$$
620 \pm 70
$$

A.D. 1330

\section{P.PHM Site A-62, Texas}

Charcoal from Panhandle aspect village on Canadian River $\left(35^{\circ} 42^{\prime}\right.$ N Lat, $101^{\circ} 34^{\prime}$ W Long). Coll. 1957 by Jack T. Hughes; subm. by D. A. Baerreis.

\section{WIS-141. P.PHM Site A-62}

Composite sample.

WIS-134. P-PHM Site A-62

Composite sample. $\mathbf{5 8 0} \pm \mathbf{7 0}$

A.D. 1370

A.D. 1300

\section{WIS-132. Palisades shelter, P-PHM}

\section{Site A-530, Texas}

A.D. 1080

$870 \pm 70$

Charcoal from Texas Panhandle aspect site, Palisades shelter, P-PHM Site A-530, in Palo Duro Canyon (35 04' N Lat, $101^{\circ} 48^{\prime} \mathrm{W}$ Long). Coll. 1963 by J. T. Hughes; subm. by D. A. Baerreis. Sample from rock hearth at NW corner of House 1 excavation.

WIS-126. P.PHM Site A-116, Texas

Charcoal from Site A-116, Panhandle aspect house on Canadian River (35 42' N Lat, $101^{\circ} 33^{\prime} \mathrm{W}$ Long). Coll. 1958 by J. T. Hughes; subm. by D. A. Baerreis. Sample from midden.

WIS-176. Currie ruin, P.PHM Site A-254, Texas A.D. 1470

$$
480 \pm 90
$$

Charcoal from Panhandle aspect house in Palo Duro Canyon $\left(35^{\circ}\right.$ 03' N Lat, $101^{\circ} 46^{\prime}$ W Long). Coll. 1956 by J. T. Hughes; subm. by D. A. Baerreis. Sample from house fill.

\section{WIS-122. Potter County site, Texas, Pt-25}

$$
660 \pm 70
$$

Charred wood from Potter County, Texas $\left(35^{\circ} 32^{\prime} 20^{\prime \prime} \mathrm{N}\right.$ Lat, $101^{\circ}$ 
$46^{\prime}$ 25" W Long). Coll. 1964 by F. E. Green; subm. by The Museum, Texas Tech. College, Lubbock. Sample from Room III, 6 in. above floor.

\section{Alibates ruin, P-PHM Site A-45, Texas}

Charcoal from Alibates ruin, Studer Site 28, Panhandle aspect village on Canadian River ( $35^{\circ} 34^{\prime} \mathrm{N}$ Lat, $101^{\circ} 40^{\prime} \mathrm{W}$ Long). Coll. 1939 by Ele M. Baker, Panhandle Plains Hist. Mus.; subm. by D. A. Baerreis.

WIS-114. Alibates ruin

Sample from Room 1.

\section{WIS-116. Alibates ruin}

Since preservative (paraffin) was visible on part of log from which specimen came, sample was extracted with petroleum ether in addition to usual treatment.

\section{WIS-129. Alibates ruin}

\section{A.D. 1180}

$$
770 \pm 75
$$

Sample from Room 19. Since sample was contaminated with paraffin, it was treated in same manner as WIS-116.

\section{WIS-118. Arrowhead Peak site, Texas}

Charcoal from Arrowhead Peak, Texas Panhandle aspect village on Canadian River (35 $03^{\prime} \mathrm{N}$ Lat, $101^{\circ} 36^{\prime} \mathrm{W}$ Long). Composite sample. Coll. 1965 by Bill Harrison and Ron Corbyn; subm. by J. T. Hughes.

\section{Roy Smith site, Oklahoma, BV14}

Charcoal from Roy Smith site, Beaver County, Oklahoma $\left(36^{\circ} 50^{\prime}\right.$ $10^{\prime \prime} \mathrm{N}$ Lat, $100^{\circ} 48^{\prime} 30^{\prime \prime} \mathrm{W}$ Long). Coll. 1965 under direction of R. E. Bell, Univ. of Oklahoma, Norman; subm. by D. A. Baerreis.

\section{WIS-124. Roy Smith site (BV14)}

$730 \pm 70$

Charcoal from Feature 2, Sq. N3-R13, in village area away from slab house ruins. Pit was 11.5 in. deep, top of pit ca. 18 in. under surface. Also found in pit were broken beveled knife and cord-marked pottery.

WIS-148. Roy Smith site (BV14)

$$
730 \pm 65
$$

Charcoal from ash lens in Sq. N37-R5 from just above bedrock, same ash lens as WIS-145 and WIS-147.

WIS-147. Roy Smith site (BV14) $\mathbf{7 0 0} \pm \mathbf{7 0}$

Charcoal from ash lens in Sq. N37-R4 ca. 2 in. above bedrock. 
WIS-121. Roy Smith site (BV14)

$730 \pm 75$

Charcoal from between two superimposed house floors in Structure A, largest room at $S$ end of compound structure at site. Floors were separated by 2 to 5 in. of rubbish and fill.

\section{WIS-145. Roy Smith site (BV14)}

$\mathbf{7 0 0} \pm 50$

Charcoal from Sq. N36-R5, an ash lens 30 in. deep.

\section{WIS-137. Roy Smith site (BV14)}

Charcoal from Test Pit B6, Feature 3, below Level \#2, 27 in. W of SE stake on $S$ wall; depth 14 in.

\section{WIS-142. Roy Smith site (BV14)}

$570 \pm 60$

Charcoal found inside slab-walled ruins, Sq. N36-R1, Level \#3, depth from 12 to 18 in. below surface. Sample has possibly been disturbed by pot-hunting activities.

\section{B. Oneota Series}

Previous date list (Wisconsin II) contained various Oneota dates from Iowa, Missouri, and Wisconsin intended to provide a sound chronology for a test of hypothesis of a climatically induced culture change within Mississippian tradition (Baerreis and Bryson, 1965).

\section{Lasley's Point village site, Wisconsin (47W N96)}

Dates are continuance of dating program reported for this site $\left(44^{\circ}\right.$ 08' N Lat, 88 41' W Long) (Wisconsin II). Coll. 1964 and 1966 through excavations supervised by G. Richard Peske, Univ. of Wisconsin, Milwaukee; subm. by D. A. Baerreis.

\section{WIS-158. Lasley's Point (47W N96)}

$470 \pm 60$

Charcoal from 9 to 16 in. below surface in Mound 28A, Test Pit 16B, Levels 2 and 3. Mound is refuse heap containing bone, shell, pottery, chert, and limestone.

\section{WIS-159. Lasley's Point (47 WN96)}

A.D. 1220

Charcoal from Level 3A, Test Pit 14.

$$
730 \pm 65
$$

\section{WIS-161. Lasley's Point (47WN96)}

$$
\mathbf{5 5 0} \pm \mathbf{7 0}
$$

Sample consisted of charred and uncharred wood and charred bone coll. 5 to 12 in. below surface in linear mound, Excavation Unit 15705015, Levels 3, 4, 5. Mound is refuse heap containing bone, shell, pottery, and chert. 
WIS-164. Lasley's Point (47WN96)

$\mathbf{4 7 0} \pm \mathbf{7 0}$

Charcoal from 10 to 22 in. below surface in Test Pit 19. Matrix was sub-humus soil containing village material and a burial.

\section{Leary site, Nebraska (25RH2)}

Leary site in Richardson County, Nebraska $\left(40^{\circ} 00^{\prime} \mathrm{N}\right.$ Lat, $95^{\circ} 24^{\prime}$ W Long) is large, important Oneota site which shows many similarities to Iowa and Minnesota sites as well as to ceramic complex at Utz site in Missouri. No prior $\mathrm{C}^{14}$ dates available. Charcoal samples tested were excavated for this purpose by J. M. Shippee of Kansas City, Missouri, in 1965 adjacent to region tested by Nebraska State Hist. Soc. in 1935 (Hill and Wedel, 1936).

WIS-155. Leary site (25RH2)

A.D. 1350

$\mathbf{5 4 0} \pm \mathbf{5 5}$

Charcoal from below plow depth and under 3 bison scapulae associated with rim of decorated pot.

WIS-151. Leary site (25RH2)

$\mathbf{7 4 0} \pm \mathbf{5 5}$

Same location as WIS-155.

\section{Utz site, Missouri (23SA2)}

Charcoal from Utz site $\left(39^{\circ} 17^{\prime} \mathrm{N}\right.$ Lat, $93^{\circ} 15^{\prime} \mathrm{W}$ Long) coll. 194950 by Carl H. Chapman, Univ. of Missouri; subm. by D. Henning, Univ. of Missouri.

WIS-167. Utz site (23SA2)

Charcoal from Trench 21, Sq. 25R4, Level \#2.

WIS-172. Utz site (23SA2)

Sample from Trench 21, refuse pit in Sq. 45R3.

\section{$490 \pm 65$ \\ A.D. 1460}

$310 \pm 60$

A.D. 1640

\section{Pipe site, Wisconsin (47FD2)}

This Oneota village, located near town of Pipe in Fond du Lac County, Wisconsin $\left(43^{\circ} 55^{\prime} \mathrm{N}\right.$ Lat, $88^{\circ} 18^{\prime} \mathrm{W}$ Long) has been briefly described in published literature (Koeppler, 1961). Charcoal from site coll. in 1958 by students under supervision of D. A. Baerreis; subm. by D. A. Baerreis.

WIS-194. Pipe site (47FD2)

$820 \pm 60$

Sample from Feature 9, a refuse pit.

A.D. 1130 


\section{Aztalan Series}

Four dates from last date list (Wisconsin II) gave a tight cluster ranging from twelfth to early thirteenth centuries in contrast to an unlikely spread from A.D. 750 to A.D. 1620 for previous dates. While newer dates were more reasonable, they were derived from a limited sector within Aztalan site (43 $04^{\prime} \mathrm{N}$ Lat, $88^{\circ} 55^{\prime} \mathrm{W}$ Long). Dating of specimens having a broader spatial provenience from within the site seemed to be desirable to demonstrate true range of site occupation.

\section{WIS-160. Aztalan site (47JE1)}

$840 \pm 70$

Charred corn kernels (id. by H. C. Cutler, Missouri Bot. Garden, St. Louis). Located $13 \mathrm{ft}$ below surface in SW pyramidal mound. Age includes correction for fractionation. Coll. 1932 by S. A. Barrett; subm. by D. A. Baerreis.

\section{WIS-162. Aztalan site (47JE1)}

$$
810 \pm 60
$$

Wooden post from structure on top of SW pyramidal mound. Mass spectrographic analysis showed no fractionation. Coll. 1951 by R. Maher (Maher, 1958); subm. by D. A. Baerreis.

\section{WIS-191. Aztalan site (47JE1)}

$$
920 \pm 55
$$

Charcoal from Feature 30, $595 \mathrm{ft} \mathrm{N}$ of stake 0:0 along $\mathrm{E}$ wall. Four post molds of "old" and two post molds of "new" stockade line were superimposed on feature which was $1.6 \mathrm{ft}$ below surface. Coll. 1962 by W. M. Hurley, Univ. of Wisconsin; subm. by D. A. Baerreis.

\section{Woodland Culture Series, Wisconsin}

The following dates are initial portion of a group designed to establish temporal placement of series of Woodland sites in Wisconsin of Middle and Early Late Woodland times. Particular emphasis was upon determination of extent of overlap of Hopewell and Effigy Mound cultures. Ultimate objective of investigation was to establish relationship of these cultures to climatic episodes, specifically the Sub-Atlantic.

\section{WIS-174. Schwert site, Wisconsin}

Charcoal (M.P.M. \#36315) from Schwert Group, a Hopewell mound group in Trempealeau County, Wisconsin $\left(43^{\circ} 59^{\prime} \mathrm{N}\right.$ Lat, $91^{\circ} 25^{\prime} \mathrm{W}$ Long). From Mound 3, Feature 10, Section 4. Coll. 1930 by W. C. McKern, (McKern, 1931); subm. by Robert Ritzenthaler, Milwaukee Public Mus., Milwaukee, Wisconsin.

WIS-182. Nitschke mound, Wisconsin A.D. 1040 $910 \pm 55$

Charcoal (M.P.M. \#32687) from Nitschke mound group, an Effigy Mound group in Dodge County, Wisconsin (43 $28^{\prime} \mathrm{N}$ Lat, $88^{\circ} 43^{\prime} \mathrm{W}$ 
Long). From "altar" in Mound 21 (panther effigy) with burial. Stone altar was situated at focal point determined by crossing of major axes of front leg and body, $0.8 \mathrm{ft}$ below surface of mound. Coll. 1927 by W. C. McKern (McKern, 1930); subm. by Robert Ritzenthaler.

WIS-196. Utley group, Wisconsin $1250 \pm 55$

Charcoal (M.P.M. \# 29605) from Utley group, Green Lake County, Wisconsin (43 $46^{\prime} \mathrm{N}$ Lat, $89^{\circ} 55^{\prime} \mathrm{W}$ Long). Sample from Mound 1 , Site 1, mound described as panther effigy (McKern, 1928). Coll. 1925 by W. C. McKern; subm. by R. Ritzenthaler.

\section{Silver Creek sites, Wisconsin (47MO1-MO3)}

A series of five small Woodland camp sites were excavated in 1962 as part of a Highway Salvage Program sponsored by State Hist. Soc. of Wisconsin (Hurley, 1966). While occupation seems to have spanned Archaic through Woodland sequences, samples were selected presumably to date a Middle Woodland house structure and this general horizon. Charcoal from Silver Creek, Monroe County, Wisconsin $\left(43^{\circ} 57^{\prime} \mathrm{N}\right.$ Lat, $90^{\circ} 42^{\prime}$ W Long) coll. 1961 by W. M. Hurley; subm. by D. A. Baerreis.

\section{WIS-163. Silver Creek site (47MO1)}

$$
2150 \pm 80
$$

Sample removed from semisubterranean house basin which had pieces of charcoal which resembled poles, ca. $3 / 4$ in. in diam. House basin was 8.1 by $6.0 \mathrm{ft}, 1.2$ to $2.2 \mathrm{ft}$ below surface. Above house basin were recovered a Middle Woodland Steuben Punctated sherd and a dentate stamped Middle Woodland sherd.

\section{WIS-169. Silver Creek site (47MO3)}

$4720 \pm 75$

Sample from Feature 5 of Silver Creek III in Sq. G101, depth from 1.65 to $3.05 \mathrm{ft}$ below surface. Should date Early Woodland and Early Middle Woodland occupations of site as represented by Early Woodland and Havana ware ceramics. Feature was devoid of artifacts. Date suggests its origin antedates Early Woodland horizon.

\section{Sanders site, Wisconsin (47W P26)}

No prior excavations had been conducted in this primarily Effigy Mound village and mound group in Waupaca County, Wisconsin (44 ${ }^{\circ}$ $16^{\prime} \mathrm{N}$ Lat, $88^{\circ} 51^{\prime} \mathrm{W}$ Long) prior to testing in 1965 and extensive excavations in 1966 under field supervision of W. M. Hurley; subm. by W. M. Hurley.

\section{WIS-171. Sanders site (47WP26)}

$$
1070 \pm 70
$$

Charcoal recovered from prehistoric circular pit which contained 
pottery vessel and assorted fragments. Pit extended from 2.0 to $2.6 \mathrm{ft}$ below surface of conical Mound 2.

\section{WIS-177. Sanders site (47WP26)}

$$
1070 \pm 70
$$
A.D. 880

Sample recovered from excavated level 18 to $24 \mathrm{in}$. below surface of Mound 3, a linear mound. Excavation test sequence contained fragments of female human cranium.

\section{Dietz site, Wisconsin 47DA12}

Initial excavations at Dietz site, Dane County, Wisconsin $\left(43^{\circ} 04^{\prime} \mathrm{N}\right.$ Lat, $89^{\circ} 23^{\prime} \mathrm{W}$ Long) in 1955 revealed Woodland cultural complex suggestive of a time of transition from dominance of Madison Cord Impressed to Aztalan Collared (Baerreis and Nero, 1956).

\section{WIS-193. Dietz site (47DA12)}

$\mathbf{7 8 0} \pm \mathbf{5 0}$

Charcoal from Dietz site, from storage or refuse pit, Feature 19. Coll. 1957 and subm. by D. A. Baerreis.

\section{Stonefield site, Wisconsin (47GT1)}

Salvage excavations were conducted in 1956 on the plantation (Stonefield) in Grant County, Wisconsin (42 $51^{\prime} 16^{\prime \prime} \mathrm{N}$ Lat, $91^{\circ} 01^{\prime} 03^{\prime \prime} \mathrm{W}$ Long) developed by Nelson Dewey, Wisconsin's first governor, where a typical nineteenth century Wisconsin village has been reconstructed. Evidence of late Middle Woodland village was revealed with ceramics suggestive of Weaver style of decoration. Coll. 1956 and subm. by D. A. Baerreis.

\section{WIS-150. Stonefield site (47GT1)}

$1520 \pm 70$

Sample from Feature 4, 13 in. below surface of feature.

\section{WIS-154. Stonefield site (47GT1)}

$1780 \pm 75$

Sample from Feature 10, lower part of pit.

\section{Bigelow site, Wisconsin (47PT29)}

This mound group and associated village $\left(44^{\circ} 28^{\prime} \mathrm{N}\right.$ Lat, $89^{\circ} 33^{\prime} \mathrm{W}$ Long), both of Effigy Mound culture affiliation, were tested in summer of 1965 and more extensively excavated in summer of 1966 under field supervision of W. M. Hurley. An historic component which was not recognized until the second field season may account for the late date, WIS-157. Results of some earlier excavations at site have been published (Blake, 1961). 
WIS-157. Bigelow site (47PT29)

$$
340 \pm 65
$$

Sample removed from $\mathrm{E}$ wall of Feature 1 of Mound $\mathrm{P}$, a linear mound. Feature extended from 8 to $13 \mathrm{in}$. below surface.

WIS-168. Bigelow site (47PT29)

$\mathbf{8 3 0} \pm \mathbf{7 0}$

Charcoal with appearance of small logs from Feature 3, Sq. S60RO, Level 4, Mound N, a bird effigy. Pit contained cord-marked pottery.

WIS-187. Bigelow site (47PT29)

A.D. 1370

$580 \pm 65$

Sample from prehistoric pit, Feature 6 in Sq. N155 W40, depth 2.2 to $3.1 \mathrm{ft}$ below surface.

\section{WIS-192. Bigelow site (47PT29)}

$$
1120 \pm 55
$$

A.D. 830

Sample from conical mound, Mound 4, Feature 1, part of group of 13 conical mounds. Feature extended from 1.0 to $1.4 \mathrm{ft}$ below surface, contained grit-tempered body sherds and a Madison Plain rimsherd. Conical mound also had a cremation in shallow pit in Alb horizon.

\section{Spencer Lake site series, Wisconsin (47BT2)}

Although original investigator of Clam River focus (McKern, 1963) interpreted the complex as dating from early 17 th century, a series of $\mathrm{C}^{14}$ dates (M-1581, M-1582, M-1583 and M-1596; Michigan XII, unpub.) suggest a substantially greater antiquity. To provide check on validity of new age assignments, a series of parallel charcoal samples from Spencer Lake site, Burnett County, Wisconsin (45 $45^{\prime} \mathrm{N}$ Lat, $92^{\circ} 18^{\prime} \mathrm{W}$ Long) were processed in Wisconsin lab. To check on possibility of contamination by preservative in these samples, half of each sample was extracted with acetone and with petroleum ether before usual acid treatment. In view of lack of systematic deviation between paired samples, it would not appear that preservatives were used. $\mathrm{C}^{12} / \mathrm{C}^{13}$ analyses of the extracted and unextracted fractions showed no fractionation. Charcoal coll. 1936 by W. C. McKern; subm. by R. Ritzenthaler.

WIS-180. Spencer Lake site (47BT2)

$$
1060 \pm 65
$$

Charcoal from Mound 1, Feature 10.

WIS-181. Spencer Lake site (47BT2)

$$
1190 \pm 60
$$

Same as WIS-180 but extracted with acetone and petroleum ether.

WIS-183. Spencer Lake site (47BT2)

A.D. 750

$$
1200 \pm 60
$$

Charcoal and charred wood from Mound 1, Feature 7. 
WIS-186. Spencer Lake site (47BT2)

$1050 \pm 50$

Same as WIS-183 but extracted with acetone and petroleum ether.

\section{E. Oklahoma}

Spiro site, Craig mound, Oklahoma (LF-40 [LfCr1])

Charcoal from Craig mound, Spiro site, Le Flore County, Oklahoma (35 18 $18^{\prime} 45^{\prime \prime} \mathrm{N}$ Lat, 94 $34^{\prime} 00^{\prime \prime} \mathrm{W}$ Long). Coll. 1937 by F. E. Clements; subm. by J. A. Brown, Univ. of Oklahoma, Norman.

\section{WIS-130. Spiro site, Craig mound}

(LF-40[LfCr1])

$\mathbf{7 8 0} \pm \mathbf{7 0}$

Sample from Feature B-189-25, charred post in grave between and $\mathrm{W}$ of main and second mound units. Associated with sample were Spiro engraved bowls and bottles (Bell, 1953), several groups of projectile points, a long-stemmed clay pipe, many shell and seed beads, and other materials.

\section{WIS-135. Spiro site, Craig mound} (LF-40[LfCr1])

A.D. 1240

$710 \pm 70$

Sample from Feature B-174-5, a grave located along W margin of Craig mound. Associated with grave were a Maxey noded Redware bottle, 2 pairs of stone earspools, 2 groups of projectile points, and textiles.

\section{WIS-156. Spiro mound complex, Oklahoma $\quad 1020 \pm 70$ \\ (LF-46 [Lf-BrI]) A.D. 930}

Charcoal and mud from burned house, Mound 1, "fire pit" 5, Le Flore County, Oklahoma (35० $18^{\prime} 45^{\prime \prime} \mathrm{N}$ Lat, $94^{\circ} 34^{\prime} 00^{\prime \prime} \mathrm{W}$ Long). Sample from charred framework of a destroyed charnel (?) house covered by a mound and located in westernmost position in upland ring of mounds (Brown, 1964). Coll. 1937 by F. E. Clements; subm. by D. A. Baerreis.

\section{WIS-123. Brown site, Oklahoma (GD-1)}

$\mathbf{7 0 0} \pm \mathbf{7 0}$

Charcoal from Brown site, Grady County, Oklahoma $\left(35^{\circ} 57^{\prime} \mathrm{N}\right.$ Lat, $98^{\circ} 13^{\prime}$ W Long), Test Pit 1, a Washita River focus component (Schmitt and Toldan, 1953). Coll. 1965 by R. E. Bell; subm. by D. A. Baerreis.

\section{F. Central and South America}

\section{Los Cerritos sites, Guayas Province, Ecuador}

Two samples of charcoal obtained from "Los Cerritos" site, $1.5 \mathrm{~km}$ $S$ of village of San Pablo, Guayas Province, Ecuador $\left(2^{\circ} 9^{\prime} \mathrm{S}\right.$ Lat, $80^{\circ}$ 47' W Long). Coll. 1963 by C. Zevallos Menendez, Univ. of Guayaquil, Ecuador; subm. by Mary Nay, Univ. of Wisconsin. 
WIS-115. Los Cerritos site, Ecuador

Charcoal from third or lowest occupation level, $2 \mathrm{~m}$ below surface. Found in association with a cranium upon which a successful trepanning is believed to have been performed. At same occupation level was found small piece of copper.

\section{WIS-125. Los Cerritos site, Ecuador}

$2540 \pm 80$

590 в.c.

Charcoal sample from second occupation level, $1.5 \mathrm{~m}$ below surface.

\section{Sayil, Yucatan, Mexico}

Visible ruins at Mayan city of Sayil, Yucatan, Mexico $\left(20^{\circ} 15^{\prime} \mathrm{N}\right.$ Lat, $89^{\circ} 40^{\prime} \mathrm{W}$ Long) are of Late Classic period (A.D. 600-900) (Stierlin, 1964).

\section{WIS-144. Sayil, Yucatan}

$1100 \pm 70$

Wood, Achras Zapota (id. by Forest Products Lab., Madison, Wisconsin), from tie beam on interior vault of the Palace. Coll. 1963 by Dick Stith, Univ. of Wisconsin; subm. by Dick Stith.

$$
\text { G. Japan }
$$

\section{WIS-178. Yubetsu site}

$7100 \pm 115$

Charcoal associated with Blade Arrowhead complex at Locality 4 (Area B), brown soil horizon, Yubetsu, Mombetsu, Hokkaido (44 20' $\mathrm{N}$ Lat, $143^{\circ} 137^{\prime}$ E Long) (Kopama and Oba, 1958). Coll. 1956 by T. Oba, Univ. of Hokkaido; subm. by C. S. Chard.

\section{WIS-175. Kojohama site \\ $5190 \pm 80$ \\ 3240 B.c.}

Charcoal associated with shell layer, 42 to $102 \mathrm{~cm}$ below surface, thought to belong to Hokoto type development at Kojohama, Locality Z, Kojohama, Shiraoi, Hokkaido (42 $27^{\prime} \mathrm{N}$ Lat, $141^{\circ} 14^{\prime} \mathrm{E}$ Long) (Oba, Ogiya, and Takeda, 1962). Coll. 1961 by T. Oba; subm. by C. S. Chard.

\section{GEOLOGIC SAMPLES \\ A. Northwest Territories}

\section{Southwest Keewatin series}

The study of past vegetation and climate at this site at $\mathrm{S}$ edge of the tundra was continued (Bryson et al., 1965). A pollen diagram and plant macrofossil analysis by Nichols, supported by studies of fossil soil (Bryson et al., 1965), provide evidence for movements of forest limits, probably in response to climatic change (Bryson, 1966). Numerous $\mathrm{C}^{14}$ assays of peat samples from Ennadai Lake pollen diagram (Wisconsin II) show that 
the inferred climatic changes, some of which were marked by changes in peat humification as well as by pollen representation, paralleled and were synchronous with those of $\mathrm{N}$ Europe (Nichols, in press). Dates reported here are for vegetational changes reflected in pollen diagrams. Sphagnum peat, $1.5 \mathrm{~m}$ monolith, coll. 1963 at Ennadai Lake $\left(61^{\circ} 10^{\prime}\right.$ $\mathrm{N}$ Lat, $100^{\circ} 55^{\prime} \mathrm{W}$ Long) by R. A. Bryson and J. Larsen; subm. by H. Nichols.

WIS-133. Ennadai Lake, N.W.T.

$630 \pm 70$

Humified Sphagnum peat, 4 to $6 \mathrm{~cm}$ below modern surface. Marks final cessation of peat growth.

W IS-127. Ennadai Lake, N.W.T.

$1250 \pm 75$

Humified Sphagnum peat, 34 to $36 \mathrm{~cm}$ below surface, level where humified peat separates fresher Sphagnum peat.

WIS-139. Ennadai Lake, N.W.T.

$3140 \pm 105$

Unhumified Sphagnum peat, 72 to $74 \mathrm{~cm}$ below surface, which forms a "recurrence surface."

WIS-166. Ennadai Lake, N.W.T.

$4800 \pm 90$

2850 B.C

Sphagnum peat 108 to $110 \mathrm{~cm}$ depth. Represents increase in peat humification and start of decline in Picea percentages in Ennadai pollen diagram after prolonged high values. This may indicate onset of cooler conditions and may correspond to beginning of Sub-Boreal zone in $\mathrm{N}$ Europe.

WIS-136. Artillery Lake, N.W.T.

$2140 \pm 80$

190 B.c.

Sampled charcoal from layer overlying a fossil podzol soil profile and beneath approx. $18 \mathrm{in}$. of eolian sand, within a quarter mile of base of esker along Lockhart River between Artillery and Ptarmigan Lakes, Mackenzie, Northwest Territories (63 $20^{\prime} \mathrm{N}$ Lat, $107^{\circ} 31^{\prime} \mathrm{W}$ Long). Charcoal presumably represents former forest cover, similar to that at Ennadai Lake (Bryson et al., 1965). Area is now approx. $40 \mathrm{mi} \mathrm{N}$ of existing forest border. Coll. and subm. by James A. Larsen, Univ. of Wiscon$\sin$.

\section{Lynn Lake, Manitoba}

\section{B. Manitoba}

Dating of Lynn Lake, Manitoba (56 $56^{\circ} \mathrm{N}$ Lat, $101^{\circ} 3^{\prime} \mathrm{W}$ Long) peat monolith was continued (Wisconsin II). Sample was intended to date vegetation change reflected in Lynn Lake pollen diagram (anal. by $H$. Nichols) but result is too old to be consistent with five other dates for this diagram. Coll. and subm. by H. Nichols. 
WIS-131. Lynn Lake, Manitoba

Sedge peat 58 to $60 \mathrm{~cm}$ below modern surface of peat bank.

\section{Clearwater Bog, The Pas, Manitoba}

Monolith from $80-\mathrm{cm}$ peat section overlying lacustrine beach sand was recovered from side of Clearwater Lake $\left(53^{\circ} 59^{\prime} \mathrm{N}\right.$ Lat, $101^{\circ} 12^{\prime} \mathrm{W}$ Long) by R. A. Bryson, 1964; subm. by H. Nichols. Monolith was divided into 2-cm slices for $\mathrm{C}^{14}$ assay and macro-fossil analysis by Nichols, and a pollen diagram was constructed. Start of peat accumulation and marked changes in humification of Sphagnum peat have been dated.

WIS-153. Clearwater Bog, Manitoba

Sphagnum peat, 26 to $30 \mathrm{~cm}$ below surface.

modern

WIS-170. Clearwater Bog, Manitoba

modern

Sphagnum peat, 62 to $63 \mathrm{~cm}$ depth.

WIS-179. Clearwater Bog, Manitoba

$410 \pm 60$

Sphagnum peat, 70 to $72 \mathrm{~cm}$ depth.

A.D. 1540

WIS-173. Clearwater Bog, Manitoba

A.D. 1010

Basal Sphagnum peat, $78-80 \mathrm{~cm}$ depth.

$$
1280 \pm 75
$$

WIS-146. Clearwater Bog, Manitoba

A.D. 670

Slice of spruce (Picea) from 80 to $82 \mathrm{~cm}$ below modern bog surface, on sand occurring at $83 \mathrm{~cm}$, overlain by $80 \mathrm{~cm}$ of peat.

\section{Louisiana}

\section{Little Bayou Sara, Louisiana}

In S Louisiana an undated assemblage of Quaternary plant macrofossils described by C. A. Brown (1938) as containing representatives of a northern flora was relocated with advice of Dr. H. V. Howe (Louisiana State Univ., Baton Rouge). Brown considered his identification of Boreal element might represent plant migration in response to Wisconsin glaciation. Post-glacial date given below suggests that this may have been relict community. Organic lens (logs, twigs, leaves, fruit) $1 \mathrm{~m}$ thick lay on green clayey silt and was overlain by sand and gravel, exposed by stream ac-

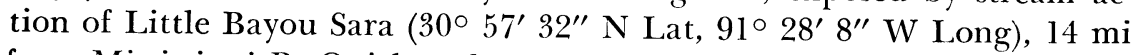
from Mississippi R. Quicksand surrounded site. Coll. 1966 and subm. by H. Nichols, Univ. of Wisconsin. 
$7240 \pm 95$

WIS-165. Little Bayou Sara, Louisiana

5290 B.C.

Wood from interior of Platanus occidentalis $\log$ (id. by R. C. Koeppen, Forest Products Lab., Madison, Wisconsin). $\mathrm{C}^{13} / \mathrm{C}^{12}$ analysis showed no fractionation.

\section{Colorado}

\section{WIS-140. San Juan Mountains, Colorado}

$6730 \pm 110$

4780 в.c.

Wood fragments separated from matrix, 170 to $180 \mathrm{~cm}$ below surface of bog in San Juan Mountains, Colorado, between Columbine Lake and U.S. Highway $550\left(37^{\circ} 37^{\prime} \mathrm{N}\right.$ Lat, $107^{\circ} 48^{\prime} \mathrm{W}$ Long), $8840 \mathrm{ft}$ above sealevel. Wood interval lay $10 \mathrm{~cm}$ above silt and pebbles apparently deposited during last glacial stadial in San Juan Mountains. Coll. 1963 and subm. by L. J. Maher, Jr., Univ. of Wisconsin.

\section{CHECK SAMPLES}

$$
2620 \pm 60
$$

WIS-143.

670 B.C.

Same as P-898, $757 \pm 52$ в.c. (Pennsylvania IX).

REFERENCES

Date lists

Pennsylvania IX Stuckenrath, Coe, and Ralph, 1966

Wisconsin II Bender, Bryson, and Baerreis, 1966

Baerreis, David A. and Bryson, Reid A., 1965, Climatic episodes and the dating of the Mississippian Cultures: Wisconsin Archaeologist, v. 46, no. 4, p. 203-220.

1966, Dating the Panhandle aspect Cultures: Bull. of Oklahoma Anthropol. Soc., v. 14, p. 105-116.

Baerreis, David A. and Nero, Robert, 1956, The storage pits of the Dietz site (Dal2) and their contents: The Wisconsin Archaeologist, v. 37, no. 1, p. 5-18.

Barrett, S. A., 1933, Ancient Aztalan: Bull. of Public Mus. of City of Milwaukee, v. 13.

Bell, R. E., 1953, Pottery vessels from the Spiro Mound: Bull. of Oklahoma Anthropol. Soc., v. 1, p. 25-38.

Bender, Margaret M., Bryson, Reid A., and Baerreis, David A., 1966, University of Wisconsin radiocarbon dates II: Radiocarbon, v. 8, p. 522-533.

Blake, Bradley, 1961, Portage County site report: The Wisconsin Archaeologist, v. 42, no. 2 , p. 57-76.

Brown, C. A., 1938, The flora of Pleistocene deposits in the Western Florida Parishes, West Feliciana Parish, and East Baton Rouge Parish, Louisiana: Louisiana Dept. Conserv. Bull., v. 12, p. 59-96.

Brown, J. A., 1964, Report on the first year's analysis of the Spiro Mound Group, Le Flore County, Oklahoma: The first Annual Report of Caddoan Archaeol., Spiro Focus Research, Univ. of Oklahoma.

Brrson, Reid A., Irving, William N., and Larsen, James A., 1965, Radiocarbon and soils evidence of former forest in the southern Canadian tundra: Science, v. 147, p. $46-48$.

Bryson, Reid A., 1966, Airmasses, streamlines, and the Boreal forest: Univ. of Wisconsin, Dept. of Meteorology, Tech. Report no. 24, 73 p.

Hill, A. T., and Wedel, Waldo R., 1936, Excavations at the Leary Indian village and burial site, Richardson County, Nebraska: Nebraska History Magazine, v. 17, no. 1, p. 3-73. 
Hurley, William M., 1966, The Silver Creek sites (47Mol to Mo5), a complex of five Woodland site localities in Monroe County, Wisconsin: M.S. thesis, Univ. of Wisconsin.

Kodama, Sakuzaemon, and Oba, Toshio, 1958, On the excavation of the Yubetsu site: a site of a Blade culture associated with Blade Arrowheads: Hoppo Bunka Kenkyu Hokoku, no. 13, p. 53-114.

Koeppler, Paul, 1961, The Pipe site: The Wisconsin Archaeologist, v. 42, no. 4, p. 174-177.

Maher, R. F., 1958, The excavation and reconstruction of the Southwest pyramidal mound at Aztalan: Wisconsin Archaeologist, v. 39, no. 1, p. 77-101.

McKern, W. C., 1928, The Neale and McClaughry mound groups: Bull. of Public Mus. City of Milwaukee, v. 3 , no. 3 .

1930, The Kletzien and Nitschke mound groups: Bull. of Public Mus. City of Milwaukee, v. 3, no. 4.

1931, A Wisconsin variant of the Hopewell culture: Bull. of Public Mus. City of Milwaukee, v. 10 , no. 2.

v. 9. 1963, The Clam River Focus: Milwaukee Public Mus., Pubs. in Anthropol.,

Nichols, H., Central Canadian palynology and its relevance to northwestern Europe in the Late Quaternary period: Proc. Second Internat. Conf. on Palynology, Utrecht, (in press).

Oba, Toshio, Ogiya, Masayasu, and Takeda, Teruo, 1962, On the excavation of the Kojohama site, Shiraoi County: Hoppo Bunka Kenkyu Hokoku, no. 17, p. 61-106, Sapporo.

Schmitt, Karl, and Toldan, Raymond, Jr., 1953, The Brown site, GD-1, Grady County, Oklahoma: Bull. of Texas Archaeol. Soc., v. 24, p. 141-176.

Stierlin, Henri, 1964, Living Architecture: Mayan: New York, Grosset and Dunlap, p. 111.

Stuckenrath, R., Jr., Coe, W. R., and Ralph, E., 1966, University of Pennsylvania radiocarbon dates IX: Radiocarbon, v. 8, p. 348-385. 